some striking remarks about embryos of birds and of fishes; while he considers Albert's book "De Plantis " as the best work on natural history produced during the Middle Ages. Albert seems to be at a loss, however, in his attempt to draw up any general account of plants, since he reaches no satisfactory basis of classification, and is equally ignorant both of their minute structure and their true mode of reproduction. Yet his descriptions are fairly accurate, and show that he had a remarkable gift of observation.

These general remarks illustrate the range of Albert's knowledge and scientific interests. He probably wrote also on mathematics, as he often refers to his mathematical works, especially the 15th and 16th books of his geometry (iii. Met. $2,1)$; but these works have not reached us. We know, however, that Albert placed mathematics between metaphysics and natural science, the object of mathematics being defined as the motion and material extension of natural objects independently of their essence and their fundamental causes. The mathematician studies the straight line for example, as it is materially illustrated in Nature, but he does not consider the cause of the straight line or the particular matter which illus- trates it. Such considerations were possible, of course, at a time when Euclidean geometry was the only known system in terms of which Nature could be interpreted.

To-day these and the other scientific views of Albert the Great could scarcely bear the strain of a searching criticism It would be unfair, however, to dismiss Albert's claims to consideration because they do not correspond to the extraordinary developments of modern science. Should one ignore Aristotle or Plato because his biology or his cosmology is behind the present state of science? Every system of philosophy has to give some account of Nature, with reference to the scientific beliefs of the time. None of the great thinkers of the past could have possibly established his doctrines in terms of the science of the future; nevertheless, one studies them as they are and often uses them in the interpretation of modern scientific conceptions. The scientific doctrines of Albert the Great are entitled to a similar consideration; and the historian who devotes his patient efforts to the study of the "doctor universalis" will be repaid to the full by the discovery of the valuable indications contained in his writings.

\title{
The Iron and Steel Industry
}

$\mathrm{M}$ R. BOFFIN, it may be remembered, introduced Mr. Weg to Mrs. Boffin as "the gentleman that's a going to decline and fall off the Rooshan Empire". Prof. W. A. Bone may be introduced as the gentleman who has taken the opportunity, as Melchett medallist of the Institute of Fuel, to decline and fall off our coal and iron industry. Behind the subject he discussed, "A Century of Fuel Economy "-in (1) the manufacture of iron and steel, (2) of gas and coke and (3) in the production of power-lies the gradual decay of our iron industry. If European nations agree to disarm, if we continue to develop the use of the road engine, the interest in iron must pass over to nations like Japan and China-to the unsettled East. The topic is, therefore, one of extreme public importance.

Born in a region of coal and raised in the reek of coke-oven, gas-producer and blast-furnace, a lifelong student of the processes, Prof. Bone is a man of fuel by instinct, able to envisage and discuss the problems, both of coal and of iron, with detachment and a fullness of ripened knowledge which no other worker, either industrial or academic, has at his command. He is the recognised master artificer in the field of high temperature change, especially in gases. By his recent systematic studies of coal he has revolutionised our conception of its nature. The special department he has developed at South Kensington stands alone and unrivalled in the completeness of its equipment and the accuracy of its apposite inquiries. The Institute of Fuel could not have paid a greater compliment to the man whose memory the medal commemorates, nor have done a greater service to industrial interests, than it has in making him its medallist and so forcing him to display his knowledge of the subject, which is probably, at the moment, the most important to be considered in the whole range of industrial activity.

The story opens with the downfall, as politician, of the Duke of Wellington, in 1832, and the coincident introduction, by the Scot,.J. B. Neilson, of the hot blast, the first great step in the modern development of the iron industry, signalling the dawn of fuel economy. Neilson appears to have been a most remarkable man and a pioneer in technical education. He had intuitively guessed. that the expenditure of a given quantity of fuel (small coal) outside the furnace for the purpose of preheating the ingoing blast would save many times more fuel (coke) inside the furnace. Paradoxical though it seemed at first, trial soon proved him to be right.

The output of Scottish pig-iron rose from 37,500 tons in 1830 to 196,960 in 1839 and to 475,000 tons in 1845. Next came the utilisation of the furnace gases but not until after 1845, when the great. Bunsen and his pupil Lyon Playfair reported to the British Association the result of their analyses of the gases, taken at various levels, from a coalfired blast furnace, pointing out that $81 \cdot 54$ per cent of the fuel was lost in the form of combustible matter, only 18.46 of the whole fuel being realised in carrying out the processes in the furnace. The second invasion of the chemist into the industry was Lowthian Bell's great inquiry (1868-72) into the complex chemical interactions within the blast 
furnace. Lowthian Bell stands alone as the colossus of the industry: he has yet to be monumentised.

Steel was also advancing. Coincidently, strange to say, with Perkin's discovery of the first coal tar colour, came Henry Bessemer's invention (1856) of his process, in which iron, taken directly from the blast furnace, was converted into steel by merely blowing air through the molten metal. A great further advance was made, in 1880, when Thomas and Gilchrist substituted a basic for the acid lining of the Bessemer furnace. This, however, threw open the production of iron to the world, as it made possible the use of low grade phosphatic ores, which were previously unworkable. It also greatly aided agriculture, by the introduction of basic slag. It is noteworthy that this advance was practically coincident with that caused by the introduction of azo dyestuffs, which threw the colour industry open to the world. Great Britain's hold upon the colour industry and upon the pig-iron industry waned at about the same time, by no mere coincidence but for similar reasons. Just as we had no second set of workers to compare with the Perkin-NicholsonHofmann triumvirate, so we had no second iron and steel triumvirate to compare with the Low thian Bell-Bessemer-Snelus cum Thomas and Gilchrist combine. Those in commercial charge of both industries were too short sighted to secure the necessary succession of scientific workers: the trained chemist has scarcely been known in the blast furnace industry. Only steel has attracted academic attention. We have recovered our hold upon colour but the blast furnace industry is still lacking in vision and has not put its house in order up to the present day ; labour difficulties have been an additional drawback. Prof. Bone holds out science as still a key of promise to some further economy in the use of fuel. Users of coal may rejoice at his conclusion but it is one that brings cold comfort to owners and producers. It is im. perative, however, that false hopes should not be held out in public in this connexion.

The century of invention Prof. Bone discusses is only about fifty years in advance of the beginning of the steel age. Children are taught something of the flint, the iron and the bronze ages; archæologists gloat over rusty bits of iron found in old Roman foundations: yet we look complacently, without wonder, at modern steel defiance of the Tower of Babel legend; this too when our ores are on the verge of exhaustion. Of the many great names mentioned in the course of the address, excepting that of Lord Playfair, scarce one of them is to be found in current literature or the histories-yet they are the men who have made our world what it is. The ministers who figure, for example, in Queen Victoria's “ Letters" have been largely automata, owing their importance almost entirely to the backing they have had in coal and steel. Politicians may trumpet their messages from Geneva and Washington but, as Shanghai shows, steel bombs are the messengers which eventually tell in forcing order. The East is too ignorant and too human ever to be reformed by mere talk: the work will needs be helped on by steel in some form.
It is because the story of steel is so ill-told in our schools, so little understood by politicians, that the public to-day has no suspicion of the way in which the world is under ferrous control. If the Highgate Hexaphilites were to name us, we should not be called Calciferites - though we have much lime in our bodies--but Ferrosoferites: iron is the great social advitant, not merely in our blood. Having gone so far in laying bare the statistics of the industry, Prof. Bone might with great advantage now prepare the way for a future Mr. Weg to decline and fall off the Empire of Coal and Steel, to which the nations, during a century past, have far too exclusively directed their attention. Everything points to a more superficial cultivation of the soil than that involved in mining for iron. Maybe the farmer will yet have his revenge and see iron put in its place, if not in Queer Street-if we no longer build warships, big guns and tanks; if the railways cease to pay because we have taken to the roads and run upon slag rather than upon steel.

The present unhappy state of the British blast furnace industry is deplorable. It was inevitable that we should lose the supremacy we once had and that countries with full command of ore and coal supplies-Belgium, France, Germany, the United States-would both satisfy their own demands and seek to be exporters. It is very doubtful if it will pay us, as long as competition is unrestricted, to supply our own needs, let alone export at a profit. Whether, under a system of regulated fair trade, we shall do so is another question. The art is not one to be lost, as we have no guarantee that the accident of war may not come upon us; moreover, much phosphate is to be gained from our low grade ores. Germany, beyond question, has greatly overbuilt her ironworks-definitely with the object of capturing outside markets. To stop armaments and yet carry on a merciless com. mercial war in iron will be to create a purely Gilbertian situation.

The rapid development of the American iron and steel industry has been a necessary consequence of the vastness of the continent; the great demand being over, it is unreasonable for the industry to expect that it can be run at full blast at the expense of other countries. The sky-scraper in New York is a logical outcome of the conditions prevailing there--of the limited area at disposal and the existence of Silurian foundations. New York, however, is no excuse for towns in the Far West out on the open prairie. The sky-scraper is simply an American habit. Is it to become one here? We are learning every day more and more to value light-why, then, should we shut it out? We know our English heating system to be more healthy than the Continental and American plan. Everyone who lives in them is beginning to complain of the beehived, graceless constructions now coming into being at the instance of speculative builders. Might we not pause to think if iron after all be worth what it is going to cost us, indirectly perhaps more than directly, in convenience, comfort and health. It has probably too long been our master.
Henry E. Armstrong. 